Dr KONSTANTINOS KATSANOS, savetnik

Ministarstvo spoljnih poslova Republike Grčke

UDK 94:327(497.1:495)"194/195"(093.2)

314.151.3-054.73(=14)(497.1)"1940/1948"(093.2)

\title{
U NOVOJ DOMOVINI Izbeglice iz Grčke u NR Makedoniji
}

\begin{abstract}
APSTRAKT: Na temelju arhivske grade i relevantne literature rad se bavi pitanjem izbeglica koji su iz Grčke pobegli u Narodnu Republiku Makedoniju tokom 1940-ih godina. Rekonstruiše se stvaranje i struktura izbegličke grupe, a analizira pitanje repatrijacije, državljanstva i imovine izbeglica u okviru jugoslovensko-grčkih odnosa. Potom je dat kratak osvrt na doprinos izbeglica procesu izgradnje slavomakedonske nacije.
\end{abstract}

Ključne reči: Grčki građanski rat, izbeglice, Grčka, Jugoslavija, slavomakedonska nacija

Pitanje grčkih izbeglica u Jugoslaviji bila je tema istraživača iz raznih zemalja, koji su se bavili mnogobrojnim aspektima tog pitanja. Među njima su bili umešanost Jugoslavije u Građanski rat u Grčkoj, sukobi Komunističke partije Grčke sa slavomakedonskim organizacijama (SNOF, NOF), život i delatnost grčkih izbeglica u Narodnoj Republici Makedoniji (NRM), odnosno Federativnoj Narodnoj Republici Jugoslaviji (FNRJ), evakuacija grčke dece, međunarodne dimenzije tog problema, delatnost emigracije u Istočnoj Evropi i pitanje repatrijacije. Pitanje izbeglica je posmatrano i u kontekstu usmene istorije, a dotaknuto je i pitanje istoriografije grčkog Građanskoga rata. ${ }^{1}$

${ }^{1}$ Od bogate bibliografije o tom pitanju, videti: Momčilo Mitrović, „Izbeglice iz Grčke u Jugoslaviji, 1945-1960. god.", Tokovi istorije, 3-4(1997), 185-199 (u daljem tekstu: Mitrović, „Izbeglice iz Grčke u Jugoslaviji“), Milan Ristović, Deca izbeglice iz Grčke u Jugo-

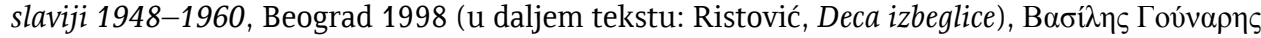

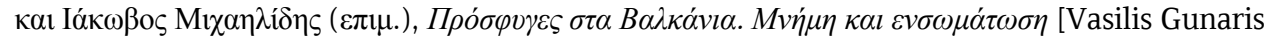
i Iakovos Mihailidis (ured.), Izbeglice na Balkanu. Sećanje i uključivanje], Atina 2004 (u daljem

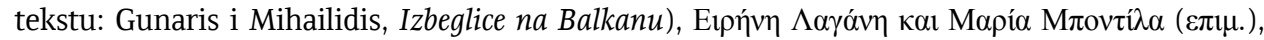

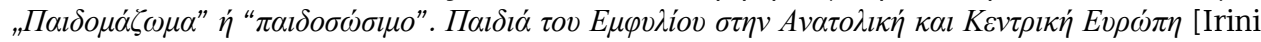
Lagani i Maria Bontila (ured.), „Otmica dece“ ili „spasenje dece“. Deca Grčkog građanskog rata u Istočnoj i Centralnoj Evropi], Solun 2012 (u daljem tekstu: Lagani i Bontila, „Otmica dece“ ili

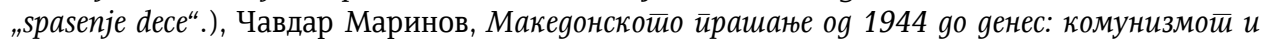


U ovom radu razmatramo neke aspekte tog pitanja na osnovu novih arhivskih podataka iz grčkih i jugoslovenskih arhiva. Istovremeno, osvrnućemo se na tradicionalna mišljenja o pojedinim aspektima izbegličkog pitanja koja su nastala u Grčkoj i Jugoslaviji tokom Građanskog rata i koja se aktuelizuju u nekim radovima današnje istoriografije.

\section{Formiranje izbegličke grupe}

U političkoj frazeologiji tokom 1940-ih godina razvilo se stereotipno shvatanje o formiranju izbegličke grupe u Jugoslaviji. Prema stavu tadašnjih rukovodilaca slavomakedonskih organizacija, izbeglice su bile žrtve Građanskog rata i prilika koje su vladale u Grčkoj posle oslobođenja od nemačkih, italijanskih i bugarskih okupatora. Prema retorici atinskih zvaničnika, svi oni koji su napustili grčku teritoriju bili su saradnici okupatora i pobegli su da bi izbegli posledice zakona ili su prihvatili slavomakedonski nacionalni identitet koji je počeo da se gradi posle 1944. godine u NRM. Obe strane su, u stvari, prikazivale formiranje izbegličke grupe prema crnobeloj šemi „otpora i kolaboracije“ ili „vinovnika i žrtava“.

Za razliku od tih stereotipnih shvatanja, izvori otkrivaju složeniju stvarnost. Izbeglička grupa u Jugoslaviji se formirala posle pojedinačnih izbegličkih talasa. Emigracija grčkih podanika počela je tokom okupacije. U periodu 1941. do 1944. bugarske okupacione vlasti su smestile, uglavnom u Bitolju, manji broj svojih saradnika. ${ }^{2}$ Druga, isto tako mala izbeglička grupa se povukla u NRM sa nemačkom vojskom prilikom njenog povlačenja iz Grčke. Bili su to uglavnom učesnici ili njihovi saradnici u kontra-četama koje su delovale u severozapadnoj Grčkoj tokom okupacije. Među njima je bilo dosta saradnika bugarskih okupatora, odnosno učesnika probugarske kolaboracionističke organizacije koja je poznata pod imenom Ohrana. ${ }^{3}$

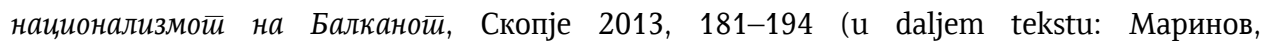

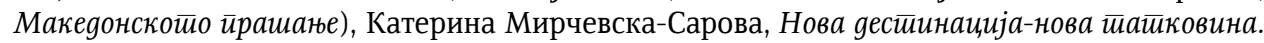

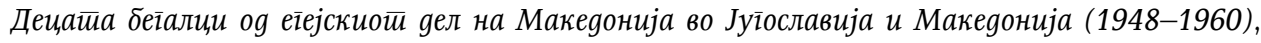

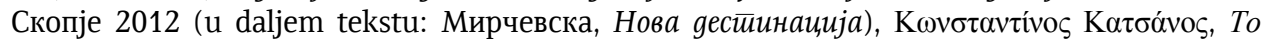

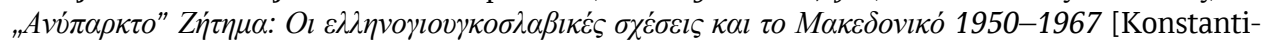
nos Katsanos, „Nepostojeće“ pitanje: Jugoslovensko-grčki odnosi i Makedonsko pitanje 19501967], Solun 2013 (u daljem tekstu: Katsanos, „Nepostojeće“ pitanje).

${ }^{2}$ Diplomatski arhiv Ministarstva inostranih poslova Srbije - Politička arhiva (u daljem tekstu DAMIPS, PA), Grčka, godina 1951, fascikla 30, dosije 21, signatura $419307 \mathrm{u}$ :

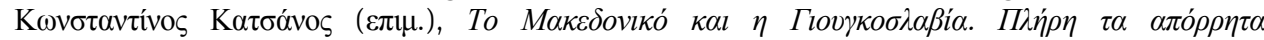

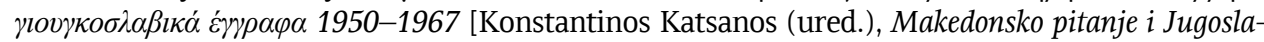
vija. Tajni jugoslovenski dokumenti 1950-1967], Solun 2009, 62-71 i 256-258 (u daljem tekstu: Katsanos, Makedonsko pitanje i Jugoslavija), Mitrović, „Izbeglice iz Grčke u Jugoslaviji“, 186-187.

${ }^{3}$ Arhiv Jugoslavije (u daljem tekstu: AJ), CK SKJ/507/II-33/V-253, Elaborat o izbeglicama iz Egejske Makedonije. Isti dokumenat je koristio i Mitrović, „Izbeglice iz Grčke u Jugoslaviji“, 185-188. 
Drugi talas se pojavio od sredine do kraja 1944. godine. U to vreme, Komunistička partija Grčke (KPG-KKE) dozvolila je stvaranje Slavomakedonskog narodnooslobodilačkog fronta (SNOF) kako bi se smanjio uticaj Ohrane među Slavofonima. ${ }^{4}$ Nekoliko meseci kasnije, zbog nacionalističke i autonomističke propagande rukovodilaca SNOF-a, KPG je rasformirala organizaciju. U znak protesta slavomakedonska grupa sa Naumom Pejovskom na čelu napustila je sredinom maja 1944. grčku teritoriju. Tokom leta, KPG je dozvolila stvaranje dva slavomakedonska bataljona. Slavomakedonski rukovodioci su uključivali u redove tih bataljona i bivše saradnike okupatora, pa je KPG odlučila da se bataljoni rasformiraju. Pripadnici ovih vojnih formacija nisu izvršili naredbu KPG i napustili su grčku teritoriju. ${ }^{5}$

Treći talas se pojavio tokom perioda „belog terora“. Pod tim izrazom se podrazumeva period od poraza levičarskih snaga u „decembarskoj pobuni" u Atini (1944) i potpisivanja sporazuma u Varkizi (12. februara 1945) o razoružanju Grčke narodnooslobodilačke armije (ELAS) do održavanja parlamentarnih izbora (31. marta 1946). U ovom burnom periodu grčke istorije vladalo je stanje opšteg nasilja. Što se slavofonskog stanovništva tiče, desničarske paravojne formacije i organi grčkih vlasti smatrali su da su slavofoni u zemlji predstavljali neku vrstu „pete kolone“ u pokušaju Jugoslavije i Bugarske da Grčkoj otmu Makedoniju. Imajući u vidu da je deo slavofonskog stanovništva svesno sarađivao sa okupatorima, vlasti su optuživale sve slavofone za kolaboracionizam. ${ }^{6}$

Svi slavofoni, naravno, nisu bili saradnici okupatora. Tokom okupacije, kako se smatra, u grčkoj Makedoniji najmanje 13.000 slavofona je izjavilo da se osećaju Bugarima. ${ }^{7}$ Prema jugoslovenskim izvorima taj broj je bio

${ }^{4}$ Pod izrazom Slavofoni se podrazumeju svi stanovnici severne Grčke koji su koristili jedan slovenski idiom, nezavisno od njihovog nacionalnog identiteta. Pod izrazom Slavomakedonci ili „Makedonci“ podrazumevaju se svi oni koji su prihvatili ideologiju o posebnoj „makedonskoj“, odnosno slavomakedonskoj naciji koja se razvila posle 1944. godina u NRM.

${ }^{5}$ Sfetas, Spyridon, „Autonomist Movements of the Slavophones in 1944: The Attitude of the Communist Party of Greece and the Protection of the Greek-Yugoslav Border", Balkan Studies, 36/2 (1995), 297-317. O priključenju bivših saradnika okupatora redovima SNOF-a, videti: AJ, CK SKJ/507/II-33/V-253, Elaborat o izbeglicama iz Egejske Makedonije.

${ }^{6}$ Mark Mazower „Three Forms of Political Justice: Greece, 1944-1945”, Mark Mazower (edit.), After the War Was Over: Reconstructing the Family, Nation, and State in Greece, 1943-1960, Princeton 2000, pp. 24-41 (u daljem tekstu: Mazower, After the War Was Over).

${ }^{7}$ Prema podacima grčkih vlasti, izjavili su da se osećaju Bugarima oko 16.000 slavofona, odnosno 4.225 u Florinskom, 3.040 u Kastorijskom i 1.382 u Eordejskom okrugu. Prema britanskim podacima njihov broj se povećao na 23.000 , a pri kraju rata spao na 13.000. Grčki funkcioner za vreme okupacije u Grčkoj Makedoniji Atanasios Hrisohou tvrdi pominje 13.000 slavofona, dok bugarski oficir Anton Kalčev navodi da je bilo 19.000 slavo-

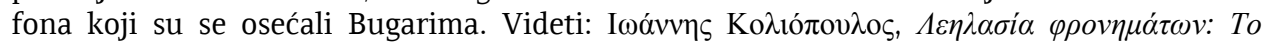

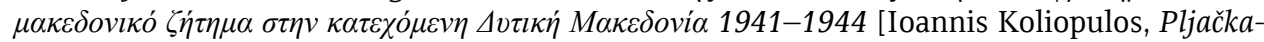


nešto manji, oko 10.000 lica, dok je broj naoružanih od strane bugarskih snaga u zapadnoj grčkoj Makedoniji iznosio 3.000-3.500 ljudi. ${ }^{8}$ Jugoslovenske vlasti su imale svest o kolaboraciji, ali su u tadašnjim prilikama preovladale političke kalkulacije. Generalni konzul Jugoslavije u Solunu A. Ilijić je krajem 1945. zabeležio da je „u našoj koloniji odnosno kod našeg življa u Grčkoj uopšte prevladavao prema okupatoru neki oportunizam, koji je za osudu s gledišta našeg narodnog shvatanja, ali koji se ne može osuditi obzirom na ciljeve naše politike, sem u slučajevima kad se radi o otvorenom kolaboracionizmu“. Isti diplomata je naglasio da "obzirom međutim na činjenicu da je naš živalj stvarno u dosta znatnom procentu surađivao sa okupatorom, napose sa Bugarima, dok se drugi deo vladao više manje oportunistički, ne može se u privođenju ovog našeg življa nacionalnoj svesti i u našem poimanju narodnih dužnosti upotrebljavati kriterij koji se upotrebljava dosledno u našoj zemlji, već je potrebno da se bude mnogo širokogrudniji, kako bi se u koloniji i našem življu uopšte moglo postepeno i da uspehom provoditi okupljanje oko Nove Jugoslavije“. ${ }^{9}$

Možda su političke kalkulacije naterale Jugoslaviju da „bude mnogo širokogrudnija“, ipak slične političke prilike su naterale grčke desničarske krugove da primenjuju princip „kolektivne odgovornosti“ protiv slavofonskog stanovništva. ${ }^{10} \mathrm{U}$ prvim mesecima 1945. formirani su specijalni sudovi i krajem aprila počelo je suđenje raznim saradnicima okupatora. Nemamo još celokupnu sliku o primeni prava protiv kolaboracionista, a posebno protiv slavofona. Prema postojećim podacima, u Florinskom okrugu, gde je broj pristalica SNOF-a bio najveći, 1945. godine bilo je 93 suđenja sa 302 optužena i 134 osuđena lica. Iduće godine broj suđenja se povećao na 261 sa 1.756 optuženih i 818 osuđenih. ${ }^{11}$ Poređenja radi, u Solunskom okrugu tokom 1945-46. godine bilo je 663 optužena i 410 osuđenih. ${ }^{12}$ Teško je utvrditi da li su ljudi pobegli zbog straha od suđenja ili su sudska rešenja

nje svesti. Makedonsko pitanje u okupacionoj zapadnoj Makedoniji 1941-1944], Solun 1994, 224-226.

${ }^{8}$ AJ, CK SKJ/507/II-33/V-253, Elaborat o izbeglicama iz Egejske Makedonije.

${ }^{9}$ AJ, 836, I-3-b/240, Generalni konzulat DFJ u Solunu - Ministarstvu inostranih poslova, Opšti pregled stanja naših ustanova i prilika u Solunu/Pov. br. 31/Solun, 5. novembar 1945.

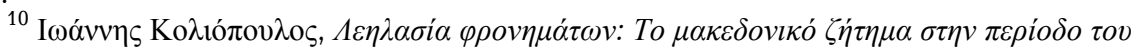

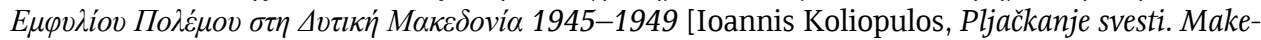
donsko pitanje u toku Građanskog rata u zapadnoj Makedoniji 1945-1949], Solun 1995, 1-38.

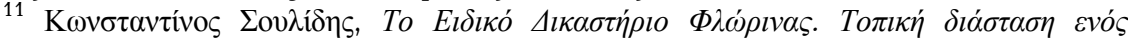

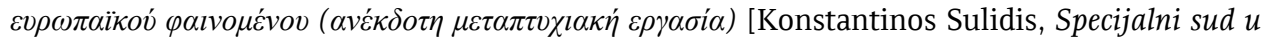
Florini. Lokalni domet jedne evropske pojave, postdiplomski rad u rukopisu], Solun 2014 (u daljem tekstu: Sulidis, Specijalni sud u Florini).

${ }^{12}$ Eleni Haidia, „The Punishment of Collaborators in Northern Greece, 19451946“, Mazower, After the War Was Over, pp. 42-61. 
prouzrokovala izbeglički talas. U svakom slučaju, u primeni prava protiv kolaboracionista u Grčkoj su preovladavali, kao i u drugim zemljama, lični i politički obračuni, etničke predrasude i želja za osvetom.

Četvrti talas se pojavio krajem 1946. i početkom 1947, kada su iz Bugarske prešli u NRM izbeglice koje su se iselile na bugarsku teritoriju tokom okupacije ili su se povukle sa grčke teritorije prateći bugarsku vojsku. ${ }^{13}$ Radilo se o licima koji su se izjasnili kao Bugari i uključili u bugarsku administraciju tokom okupacije. Posle bugarske kapitulacije stanovnici istočne grčke Makedonije počeli su masovno da beže u Bugarsku, bojeći se osvete lokalnog stanovništva. Osveta koja je kulminirala krajem 1944. bila je motivisana zločinima bugarske okupacione vojske u regionu, a posebno posle Dramskog ustanka (1941). Pored osvete, u proleće 1945. počelo je suđenje saradnicima okupatora. Gledano iz ugla bugarofilskih grčkih podanika saradnja sa bugarskom vlašću nije predstavljala saradnju sa okupatorom već služenje narodu. No, iz ugla grčkih sudova, ova delatnost je spadala u okvir otvorene kolaboracije. U toku 1945. bilo je 420 optuženih i 220 osuđenih, a 1946. godine 1.364 optužena i 1.008 osuđenih. ${ }^{14}$ Kao u Florinskom regionu, u Dramskom okrugu je većina optuženih (7 od 10) bila suđena u odsutnosti, a u datim okolnostima vladao je aksiom da je svako ko se nije pojavio pred sudom bio kriv. Deo tih izbeglica koji su bili nastanjeni u Bugarskoj tokom 1946. i 1947. godine iseljavao se u NRM. Okolnosti pod kojima su izbeglice napuštale bugarsku teritoriju postale su predmet raznih gledišta. Prema bugarskoj istoriografiji izbeglice su bile primorani na to, a prema slavomakedonskoj istoriografiji oni su dobrovoljno selili u NRM. ${ }^{15}$ Izgleda da bugarske vlasti, iako su odlučile da se izbeglice „makedonskog porekla i nacionalnosti“ deportuju u Jugoslaviju, tu meru nisu sprovodile $u$ svim mestima Bugarske. ${ }^{16}$

${ }^{13}$ DAMIPS, PA, Grčka, godina 1951, fasc. 30, dos. 21, sign. 419307 u: Katsanos, Makedonsko pitanje i Jugoslavija, 257.

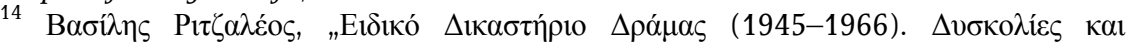

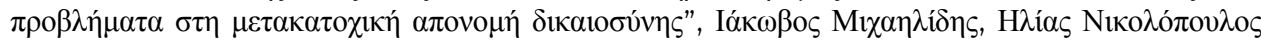

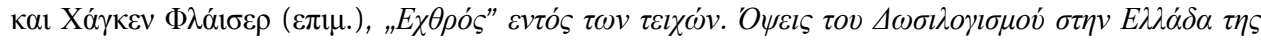

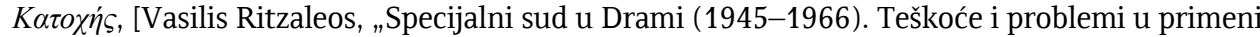
prava posle okupacije“, u Iakovos Mihailidis, Ilias Nikolakopulos i Hagen Flaiser, „Neprijatelj“ unutar zidova. Aspekti kolaboracionizma u Grčkoj tokom okupacije] Atina 2006, 365-387.

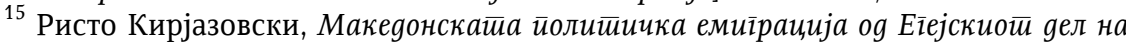

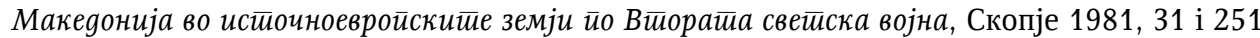

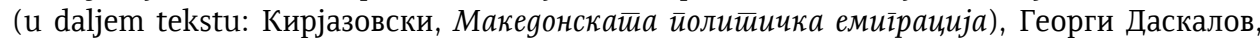

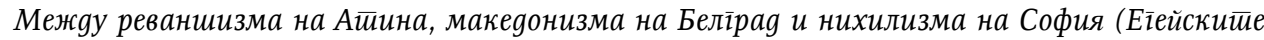

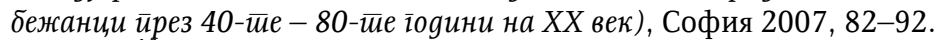

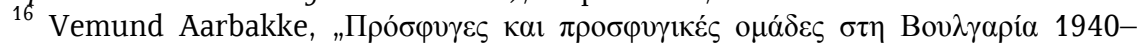
1990 [Izbeglice i izbegličke grupe u Bugarskoj 1940-1990]", Gunaris i Mihailidis, Izbeglice na Balkanu, 387-389. 
Novi izbeglički talas se pojavio tokom 1947. i 1948. godine. Radilo se uglavnom o civilnom stanovništvu pograničnih regiona, o nevinim ljudima, odnosno žrtvama Građanskog rata koje su prešle jugoslovenskogrčku granicu. U istu grupu spadaju i deca koja su evakuisana sa grčke teritorije tokom 1948. godine. Prema oceni jugoslovenskih vlasti, „motivi za ovu emigraciju su [bili] represalije grčkih vladinih trupa protiv stanovništva $\mathrm{u}$ Makedoniji u vezi sa građanskim ratom [...] U ovoj grupi pristigao je $\mathrm{u}$ NR Makedoniju i izvestan broj egejskih Makedonaca, koji su želeli da se sklone od ratnih teškoća koje su vladale na teritoriji pod kontrolom DAGa“. ${ }^{17} \mathrm{U}$ isto vreme grčku teritoriju su napustili borci Demokratske armije Grčke (DAG) koji su bili na strani Tita u sukobu sa Staljinom i protiv zvanične linije KPG. Najzad, male grupe izbeglica su prešle jugoslovensko-grčku granicu posle sloma DAG-a i završetka Građanskog rata u Grčkoj (avgust 1949).

\section{Priliv izbeglica u Jugoslaviju tokom 1940-ih}

Obe vlade su davale netačne podatke o broju izbeglica. Grčka vlada je preuveličavala broj izbeglica kako bi dokazala široke dimenzije kolaboracionizma među slavofonima. Napuštanje grčke teritorije se smatralo dokazom o saradnji sa okupatorom. Istovremeno, nastanjenje velikog broja izbeglica, odnosno lica koja su bila sposobna da nose oružje iskorišćeno je kao argumenat o velikoj opasnosti koja je pretila Grčkoj „sa Severa“. Ta slika je odgovarala retorici jugoslovenske vlade o kompaktnom slavomakedonskom življu u Grčkoj i „brutalnim metodama“ grčkog „monarhofašističkog režima" prema njemu. Istovetni su bili i argumenti o deci-izbeglicama. Grčke vlasti, govoreći o „otmici dece“, povećavale su njihov broj u pokušaju da se uveličaju osećaji „užasa“ koji je izazvao taj „danak u krvi“ i da se akcija grčkih partizana uporedi sa „janjičarstvom“. S druge strane, povećan broj grčke dece je odgovarao politici jugoslovenskih vlasti, zato što je ta slika ojačala argument o „represiji“ protiv komunista i slavomakedonaca od grčkih vlasti, ali i argument o „humanitarnoj akciji“ i „spasavanju“ grčke dece od strahota rata. ${ }^{18}$ Broj izbeglica koji su iz Grčke prešli u Jugoslaviju različito

${ }^{17}$ Katsanos, Makedonsko pitanje i Jugoslavija, 257.

${ }^{18}$ O Građanskom ratu u Grčkoj i odnosu Jugoslavije prema Grčkoj u to vreme, videti: Milan Ristović, „Jugoslavija i Građanski rat u Grčkoj (1945-1950)“; Balkan posle Dru-

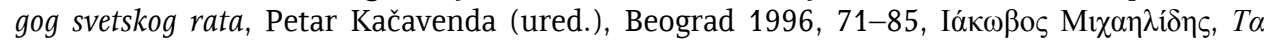

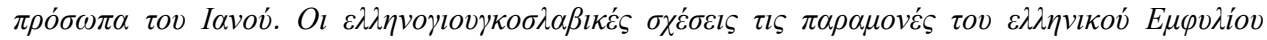

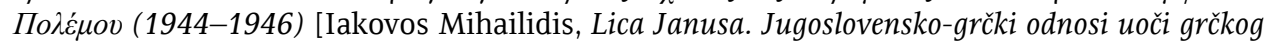

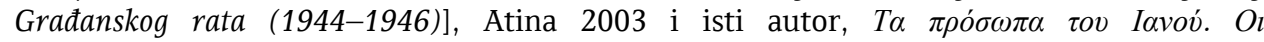

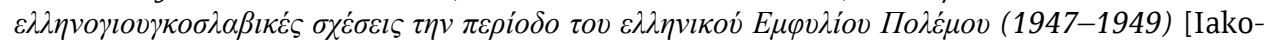
vos Mihailidis, Lica Janusa. Jugoslovensko-grčki odnosi u toku grčkog Građanskog rata (19471949)], Atina 2007. 
je procenjivan tako da se u literaturi nalaze podaci koji se kreću od 25.000 do $30.000 .^{19}$

Prema podacima jugoslovenskih vlasti, u Jugoslaviju je od početka rata do početka 1944. emigriralo 500 osoba. Te izbeglice su bugarske vlasti, kao što je već rečeno, smestile uglavnom u Bitolju. Tokom 1944. pobeglo je u NRM oko 4.000 izbeglica a sledeće, 1945. godine još 5.000. Većina tih izbeglica, 8.664 osobe, odnosno 3.328 muškaraca, 2.186 žena i 3.150 dece, nastanili su se u NRM, a ostali u drugim gradovima Jugoslavije. ${ }^{20}$ Broj izbeglica se povećao u narednim godinama. Tokom 1946. iselilo se u Jugoslaviju 8.000 osoba. Među njima su bile i izbeglice koje su u Jugoslaviju prešle preko Bugarske. Još 6.000 izbeglica prešlo je jugoslovensko-grčku granicu tokom 1947. godine. ${ }^{21} \mathrm{U}$ narednim godinama broj osoba koje su napustile grčku teritoriju se smanjivao. Tokom 1948. emigriralo je 3.000 izbeglica, njih 2.000 tokom 1949. i samo 95 lica 1950-1951. godine. Prema popisu, ukupan broj izbeglica koji su prešli u FNRJ direktno iz Grčke ili preko Bugarske do 1951. iznosio je 28.595. Posle sukoba sa Kominformom FNRJ je napustilo oko 4.000 lica, pa se broj izbeglica smanjio na 24.595. Većina tih lica - oko 19.000, živela je u NRM, oko 4.000 u dva naselja (Đakovo i Kruševlje) i 1.595 u drugim jugoslovenskim republikama. ${ }^{22}$

Jugoslovensko-grčku granicu nisu prešli samo borci „narodnooslobodilačkog rata" već i kompletne porodice. Prema arhivskim podacima, tokom 1945. u Jugoslaviji su se nastanile 1.204 porodice sa 5.402 člana. Godine 1946. broj porodica je dostigao 1.630 sa 6.270 članova. Naredne godine broj izbegličkih porodica se povećao na 2.406 sa 13.606 članova, a u toku 1948. na 3.269 porodica. ${ }^{23}$ Nedatirani popis, najverovatnije iz sredine

${ }^{19}$ Evangelos Kofos, Nationalism and Communism in Macedonia, New York 19932,

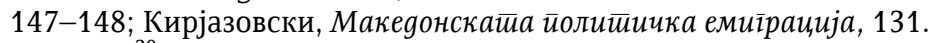

20 ДАРМ, Главен Одбор на Здружението на Бегалците од Егејска Македонија, Анализа за полижението на бежанците од Егејска Македонија во град Скопје, АJ, СK SKJ/507/II-33/V-253, Elaborat o izbeglicama iz Egejske Makedonije, Мирчевска, Нова gесиинаиија, 83.

${ }^{21}$ Uporedi: Jugoslavija 1918-1984. Zbirka dokumenata, urednici Branko Petranović i Zečević Momčilo, Beograd 1985, 830-832 - o nastanjenju 20.104 emigranta početkom 1947. u Jugoslaviju.

${ }^{22}$ DAMIPS, PA, Grčka, god. 1951, fasc. 30, dos. 21, sign. 419307, u: Katsanos, Makedonsko pitanje i Jugoslavija, 257. Izveštaj pripremljen uoči Titove posete Atini (1954) navodi da je broj izbeglica iznosio 23.000. AJ, 837, I-2/3/202-343-Monografije. Grčka, 127. Nekoliko godina kasnije, predsednik vlade NRM Ljupčo Arsov zabeležio je da je u Jugoslaviji do 1955. godine bilo nastanjeno 20.000 izbeglica, Нова Макеgонија, 20 Iavovapíov 1955. U izveštaju koji je pripremljen uoči posete grčkog premijera Konstantinosa Karamanlisa Beogradu (1956) naveden je broj od oko 30.000 izbeglica, AJ, 837, I-3-a/31-8-Informativnopolitički materijal.

${ }^{23}$ ДАРМ, Главен Одбор на Здружението на Бегалците од Егејска Македонија, Реферат на Л. Модеов за егејци. 
1949. godine, navodi da se u NRM nastanilo 4.159 porodica i 1.218 pojedinaca, ukupno 17.905 izbeglica. ${ }^{24}$ Svi popisi koje su izvršile lokalne vlasti, nezavisno od sitnih neslaganja, pokazuju da su najveći broj izbeglica $u$ NRM činile kompletne porodice.

Neslaganja o broju dece-izbeglica, ali i o dolasku u Jugoslaviju srećemo i u literaturi. Podaci se kreću od 17.529 (bez Jugoslavije) do 28.296 dece. Grčki crveni krst je u januaru 1950. računao da je grčku teritoriju napustilo 28.296 dece, od kojih su 11.600 smeštena u Jugoslaviji. Komisija „Pomoć deci“ je krajem 1949. procenjivala broj dece na 27.200, od kojih se 11.000 nastanilo u Jugoslaviji; Grčka komunistička partija navodi da 1950. broj dece, bez Jugoslavije, iznosi $17.529 .{ }^{25}$ Izvori se slažu u tome da je oko 11.000 dece bilo smešteno u Jugoslaviji, a ostala u drugim istočnoevropskim zemljama. Slične podatke je navodio i Jugoslovenski crveni krst (JCK). Prema izveštaju JCK krajem 1948. godine 1.692 dece su bila smeštena $u$ domovima JCK, a 8.908 živelo je sa roditeljima ili sa izbeglim porodicama na teritoriji NRM. ${ }^{26}$ Početkom januara 1950. JCK je izvestio Međunarodni crveni krst da se na jugoslovenskoj teritoriji nalazi 9.119 dece, od kojih je 7.274 smešteno sa roditeljima i 1.845 zbrinuto u dečijim domovima. Istovremeno JCK izveštava da je tokom 1949. godine 2.094 dece prebačeno u Čehoslovačku. Godinu i po dana kasnije, u septembru 1951, prema zvaničnom popisu izbeglica koji je izvršen u Jugoslaviji, na jugoslovenskom tlu se nalazilo 9.489 dece, od kojih 8.281 sa roditeljima i 1.208 zbrinutih u domovima. Prema istom izveštaju, od 30. marta 1948. do kraja septembra 1949. kroz Jugoslaviju je prošlo 14.028 dece. $^{27}$

Većina izbeglica, oko tri četvrtine, uključujući i decu-izbeglice smeštena je na jugoslovenskoj teritoriji pre nego što je objavljena odluka o evakuaciji dece iz grčke Makedonije, početkom marta 1948. Većinu izbeglica u Jugoslaviji činile su kompletne porodice. Bilo bi iracionalno tvrditi da su izbeglice, napustivši grčku teritoriju, ostavili svoju decu kod rođaka ili prijatelja, u očekivanju odluke Prevremene demokratske vlade Grčke o evakuaciji dece. U suštini, evakuacija dece iz Grčke na osnovu odluke Privremene demokratske vlade donete krajem februara 1948. odnosila se uglavnom na decu koja su prolazila kroz Jugoslaviju i potom se nastanjivala $u$ istočnoevropskim zemljama.

${ }^{24}$ ДАРМ, Главен Одбор на Здружението на Бегалците од Егејска Македонија, Список на бегалците од Егейска Македонйа, настанени во долните околйи на Вардарска Македонйа, поодено мажи, жени и деца, ДАРМ, Главен Одбор на Здружението на Бегалците од Егејска Македонија, За економските проблеми.

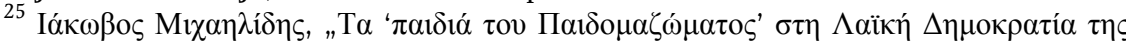

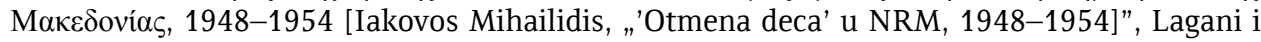
Bontila, „Otmica dece“ ili „spašenje dece“, 86.

${ }^{26}$ DAMIPS, PA, Grčka, god. 1949, fasc. 40, dos. 14, sign. 423346.

${ }^{27}$ Ristović, Deca izbeglice, 96 i 106; Katsanos, Makedonsko pitanje i Jugoslavija, 71. 


\section{Struktura izbeglica}

Izbegličko pitanje je izazvalo oštre reakcije i jugoslovenske i grčke vlade. Već je rečeno da prema stavovima tadašnjeg slavomakedonskog, odnosno jugoslovenskog rukovodstva, izbeglički talas se pojavio kao rezultat represije. To stereotipno tumačenje vezano je za isticanje brojnih i nevinih žrtava koje su Slavomakedonci podneli tokom 1940-ih godina braneći svoje nacionalne interese $u$ Grčkoj. Stereotipna je bila i retorika atinskih vlada. Izbeglički talas se pojavio kao rezultat ličnog i ideološkog izbora, pa su prema njihovim tumačenjima iz Grčke pobegli svi oni koji su bili „kolaboracionisti“ ili koji se „nisu osećali Grcima“. ${ }^{28}$

Izbeglička populacija u Jugoslaviji ipak nije bila kompaktna. Od njenog formiranja izdvajale su se razne grupe sa jasnom ideološkom i političkom orijentacijom. Ove grupe su bile podložne promenama, osobe iz jednog kruga su prelazile u drugi zavisno od razvoja događaja.

Prvoj grupi su pripadala lica koja su imala jasnu komunističku orijentaciju. Boreći se u redovima KPG ta grupa je težila pobedi komunizma i izgradnji socijalističkog društva. No, nisu svi komunisti delili isto shvatanje o stvaranju buduće države. Jedna podgrupa je prihvatala ideju ujedinjenja cele geografske Makedonije u sklopu jugoslovenske federacije. Druga podgrupa nije prihvatala jugoslovenske ideje o makedonskoj državi. Najveći deo te podgrupe je napustio Jugoslaviju posle sukoba Tita sa Staljinom i nastanio se u drugim istočnoevropskim zemljama, uključujući i Bugarsku. $^{29}$

Druga grupa je bila sačinjena od izbeglica probugarske orijentacije, pre svega onih koji su se preselili u Jugoslaviju za vreme okupacije. Jedan broj izbeglica napustio je grčku teritoriju tokom 1944. i 1945. zbog saradnje sa okupatorom i bio „širokogrudnije“ prihvaćen u Jugoslaviji. U istu grupu moramo uračunati i izbeglice iz Dramskog i Sereskog sreza koje su sarađivale sa bugarskim okupacionim vlastima i pobegle u Bugarsku zajedno sa bugarskim trupama. Ove izbeglice su 1946. prešle u NRM gde su bile smeštene i obrađivale fondovsku zemlju. Prema arhivskim izvorima, oni su „svojim radom uspeli da poboljšavaju standard svog života, i stekli priličan kapital u novcu, kao i stoci, tako da su uslovi života u NR Makedoniji, odgovarali njihovoj sklonosti za radom i obogaćivanjem“. Rešenjem jugoslovenskih

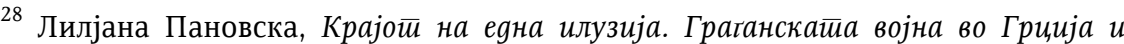
Макеgониите , 1946-1949, Скопје 2003, 24-36.

${ }^{29}$ ДАРМ, Главен Одбор на Здружението на Бегалците од Егејска Македонија, Број ег. Македонаца, АJ, 836, I-3-b/279, Ristović, „Eksperiment Buljkes - grčka republika u Jugoslaviji 1945-1949", Godišnjak za društvenu istoriju, 2-3(1997), 179-201. 
vlasti ove izbeglice su se preselile $u$ Đakovo, uprkos njihovom negativnom stavu prema toj odluci. ${ }^{30}$

Najveći deo grčkih izbeglica bile su žrtve Građanskog rata u Grčkoj. Većina izbeglica je smatrala kako je njihov premeštaj u Jugoslaviju privremen. ${ }^{31}$ Sličan je bio i pristup jugoslovenskih vlasti. Dok je rat trajao, uprkos ogromnim sredstvima koja su trošile jugoslovenske vlasti, sve mere su bile privremenog karaktera i orijentisane ka rešenju svakodnevnih potreba izbeglica. No, slaba žetva, nedostatak javnih radova i obradive zemlje koja bi mogla da se dodeli izbeglicama stvarali su dodatne teškoće. Prema izveštaju koji je sačinjen uoči posete Tita Skopju 1949. godine, „u koliko se izmene političke prilike u Grčkoj i stanje postane snošljivo najbolje bi rešenje bilo da se vrate u Grčku na svoju zemlju, jer pored toga što klimu teško podnose i sami begunci žele da se povrate na svoju zemlju“. ${ }^{32}$ Nekoliko godina kasnije, vlada NRM u dopisu MIP-u navodi da „očigledno je da cela ova masa izbeglica nije mogla nositi oružje protiv vladinih formacija, već da je u svom ogromnom delu izbeglička masa koja je u onom haotičnom stanju spasavala goli život bežeći u Jugoslaviju ne posle pobede vladinih snaga, već $\mathrm{u}$ periodu dok je građanski rat bio još u punom jeku što govori dovoljno da su ove izbeglice bile u nemogućnosti da daju aktivnu podršku jednoj ili drugoj strani, dok je rat dotle besneo". ${ }^{33}$

Većina izbeglica nije pripadala komunističkoj ideologiji. Tokom međuratnog razdoblja glasačko telo $u$ Grčkoj bilo je podeljeno na članove narodne i liberalne partije. U severnim krajevima Grčke, iseljenici iz Male Azije su bili uglavnom glasači liberalne stranke Elefteriosa Venizelosa. Slavofonska populacija je došla u sukob sa iseljenicima iz Male Azije zbog dodele zemljišta. Ekonomsko pitanje je dobilo političku dimenziju, ali ni u jednom slučaju agrarno pitanje se nije pretvorilo u etnički sukob. Pošto se Venizelos pojavio kao zaštitnik maloazijskih iseljenika, slavofoni su masovno glasali za desničarske partije, uglavnom za Narodnu partiju, najveću desničarsku stranku. U toku okupacije KPG nije uspela da proširi uticaj među slavofonskom populacijom, a kada je to pokušala preko SNOF-a došla je u sukob sa organizacijom. Osim toga, do jeseni 1946. slavomakedonska organizacija, koje je $u$ aprilu 1945. dobila ime NOF, nije imala organsku vezu sa KPG.

Kada je reč o „makedonskoj“ nacionalnoj ideologiji teško je utvrditi do koje mere je ona uhvatila koren među slavofonima u toku okupacije i u

${ }^{30}$ ДАРМ, Главен Одбор на Здружението на Бегалците од Егејска Македонија, Број ег. Македонаца.

31 ДАРМ, Главен Одбор на Здружението на Бегалците од Егејска Македонија, 1.996.40.60/410-414.

${ }^{32}$ AJ, 836, II-1/19, Izbeglice iz Egejske Makedonije.

${ }^{33}$ DAMIPS, PA, Grčka, god. 1955, fasc. 22, dos. 2, sign. 412935. 
prvim godinama posle oslobođenja. Ilija Dimovski (Goce), rukovodilac slavomakedonskog bataljona koji je napustio grčku teritoriju u oktobru 1944, govoreći na kraju 1945. o stanju izbeglica u NRM beleži da „u političkom pogledu ne postoje nikakvi uslovi za moralno i nacionalno uzdizanje, izmučenog i mizernog naroda. Ne postoje nikakva prosvetna ni agitaciona propaganda. Ne postoji nikakav politički život. Položaj u kome se nalaze emigranti može doneti velike štete, pošto reakcija iskorišćuje njihovo nezadovoljstvo i njihov mizeran život" “. ${ }^{34} \mathrm{Ni}$ nekoliko godina kasnije situacija se nije promenila, pa izveštaji jugoslovenskih vlasti govore o „niskoj političkoj i nacionalnoj svesti“ većine izbeglica. ${ }^{35}$ Iste vlasti su bile uverenja da je „stvaranje i delatnost SNOF-a, a kasnije NOF-a doprinela mnogo buđenju nacionalne svesti, kao i podizanju njihovog političkog nivoa". Izražavali su, međutim, sumnju u pogledu plodova te delatnosti budući da „se ne može sa sigurnošću tvrditi da je u potpunosti iskorenjeno u svesti, naročito starijih ljudi, bugarofilstvo". ${ }^{36}$

\section{Pitanje repatrijacije izbeglica}

Do završetka Grčkog građanskog rata izbeglice su očekivale ishod oružanih sukoba i stvaranje uslova za repatrijaciju. Dok je rat trajao grupa grčkih izbeglica, koja je došla u Jugoslaviju preko Bugarske, tražila je da joj se dozvoli povratak u Bugarsku. U martu 1948. otpravnik poslova bugarske ambasade u Beogradu obavestio je jugoslovensko Ministarstvo inostranih poslova (MIP) da je oko 3.500 izbeglica smeštenih u Đakovu tražilo posredovanje bugarske ambasade da se vrate u Bugarsku, navodeći kao razlog teške životne uslove. MIP se nije odazvao želji izbeglica i predložio je da se preduzmu mere da se njihovi životni uslovi poboljšaju, kako bi se sprečile njihove akcije za povratak u Bugarsku. ${ }^{37}$

Posle nekoliko meseci, u jeseni 1948, grčka vlada je pokrenula pitanje „otmice“ grčke dece u Organizaciji ujedinjenih nacija (UN), tražeći njihovu bezuslovnu repatrijaciju. U prvo vreme, Generalna skupština UN preporučila je vraćanje dece u Grčku pod uslovom da „deca osobno, njihove majke ili očevi, ili, u odsustvu njihovih roditelja, rođaci izraze takvu želju“. Na petom zasedanju Generalne skupštine u decembru 1950, sve države koje su dale azil grčkoj deci pozvane su „da preuzmu sve mere [...] kako bi se

${ }^{34} \mathrm{AJ}, 836, \mathrm{I}-3-\mathrm{b} / 241$.

35 ДАРМ, Главен Одбор на Здружението на Бегалците од Егејска Македонија, Анализа за полижението на бежанците од Егејска Македонија во град Скопје, ДАРМ, Главен Одбор на Здружението на Бегалците од Егејска Македонија, 1.996.40.60/410-414, AJ, CK SKJ/507/II-33/V-253, Elaborat o izbeglicama iz Egejske Makedonije.

${ }^{36}$ AJ, CK SKJ/507/II-33/V-253, Elaborat o izbeglicama iz Egejske Makedonije.

${ }^{37}$ DAMIPS, PA, Grčka, god. 1948, fasc. 59, dos. 7, sign. 49081. 
olakšao brzi povratak dece njihovim roditeljima“. Tom odlukom, Generalna skupština nije uslovila repatrijaciju dece u Grčku već vraćanje dece roditeljima nezavisno gde su se oni nalazili. ${ }^{38}$

Preporuka Generalne skupštine poklopila se sa normalizacijom diplomatskih odnosa Grčke i Jugoslavije. Normalizacijom se stvoreni uslovi za povratak ne samo dece ${ }^{39}$ već i izbeglica. Krajem 1950. oko 60 izbeglica se prijavilo grčkoj ambasadi u Beogradu, odnosno konzulatu u Skoplju i zatražilo repatrijaciju kao grčki državljani. ${ }^{40}$

Vremenom se povećavao broj izbeglica koji su se prijavljivali grčkom konzulatu. Za samo nekoliko meseci upisano je oko 3.000 izbeglica koji su želeli da se vrate u Grčku. Prema procenama jugoslovenskih vlasti, za repatrijaciju bi se prijavilo 25-30\% izbeglica pod uslovom opšte amnestije i slobodne repatrijacije. ${ }^{41}$

Ovaj potez grčkih izbeglica se tumačio na različite načine. Grčke vlasti su smatrale da su se izbeglice prijavile za povratak posle plana njihovog rukovodstva. Cilj te delatnosti, kako se pretpostavljalo, bio je pritisak na Grčku kako bi dozvolila repatrijaciju izbeglica pod uslovom da se prizna „makedonska manjina“ u Grčkoj. Loše planiranje, međutim, rezultiralo je masovnim odzivom izbeglica koji su tražili bezuslovnu repatrijaciju. Nezavisno od tih tumačenja, za grčke vlasti bila je neprihvatljiva masovna repatrijacija izbeglica.

Vlasti su delile izbeglice na one koje su „dobrovoljno“ i one koji su „silom" pristupile komunističkom pokretu. Shodno tome, bile su spremne da dozvole povratak na individualnoj osnovi onim izbeglicama koji su bili „otmeni“ iz Grčke. ${ }^{42}$ Prvih meseci 1951. grčka ambasada u Beogradu i konzulat u Skoplju izdali su nekoliko pasoša grčkim izbeglicama, koji su posle toga tražili izlazne vize. Početkom maja bilo je 127 takvih molbi u celoj Jugoslaviji. Republički organi su se odazvali molbama, osim NRM, a po izveštaju MIP-a „bilo je slučajeva da su neki od njih koji nisu dobili izlazne

38 DAMIPS, PA, Grčka, god. 1951, fasc. 30, dos. 21, sign. 419307, u: Katsanos,

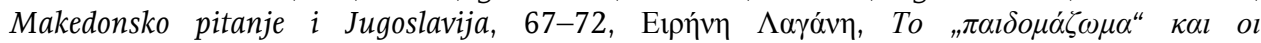

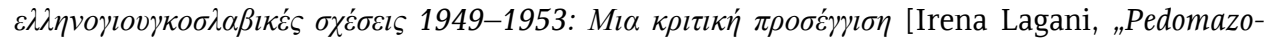
ma" i jugoslovensko-grčki odnosi 1949-1953: Kritički pristup], Atina 1996.

${ }^{39}$ Ristović, Deca izbeglice, 157-158.

${ }^{40}$ DAMIPS, PA, Grčka, god. 1951, fasc. 30, dos. 17, sign. 46799/21. maja 1951, u: Katsanos, Makedonsko pitanje i Jugoslavija, 53.

${ }^{41}$ ДАРМ, Главен Одбор на Здружението на Бегалците од Егејска Македонија, 1.996.40.60/410-414.

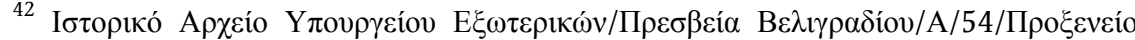

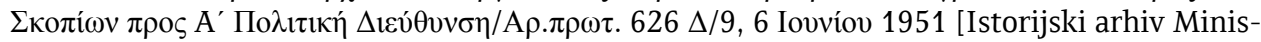
tarstva inostranih poslova Grčke/Fond: Ambasada u Beogradu (dalje IAYE/AB)/A/54/Konzulat u Skoplju Prvoj političkoj direkciji/br. pr. $626 \Delta / 9,6$. juni 1951]. 
vize u Skoplju, otišli u neku drugu narodnu republiku, tamo dobili izlazne vize i tako napustili Jugoslaviju“. ${ }^{43}$

Potezom izbeglica izbio je na površinu različit stav jugoslovenskih vlasti o repatrijaciji. Dok su druge republičke vlade dozvoljavale odlazak izbeglica, vlada NRM je procenjivala „da bi ovo bilo nezgodno" i da jugoslovenski organi nisu bili dužni da licima koja su se stavila pod jugoslovensku zaštitu izdaju izlazne vize, čak i u slučaju ako izbeglice izjave želju za repatrijacijom. ${ }^{44}$ Istovremeno, vlada NRM je preuzela restriktivne mere protiv onih koji su posećivali grčki konzulat i povezala je pitanje repatrijacije sa informacijama koje su stizale iz Grčke o iseljavanju "makedonske manjine“ u prekookeanske zemlje. ${ }^{45}$ Tvrdila je da „nema ni jednog traženja vize za odlazak u Grčku, već samo za druge zemlje. To bi govorilo o tome da Grcima nije stalo da se ti ljudi vrate u Grčku, koliko do toga da oni odu iz Makedonije, odnosno Jugoslavije“". ${ }^{46}$

Rukovodstvo MIP-a, u potraži za alternativom, postavilo je pitanje repatrijacije pred Pravni savet. Mišljenje Pravnog saveta nije ostavilo MIPu prostor za manevrisanje. Prema oceni Saveta, „ne samo da nema nikakvog pravnog osnova za sprečavanje vraćanje ovih izbeglica, koji to sami žele, a koji nisu po svojoj molbi stekli jugoslovensko državljanstvo, već bismo takvim sprečavanjem povredili jedno od najmanje spornih pravila međunarodnog prava“. ${ }^{47}$ Pošto MIP nije imao pravnih argumenata za obustavljanje odlaska izbeglica iz Jugoslavije odlučeno je da se pitanje repatrijacije poveže sa pitanjem iseljavanja "makedonske manjine“ iz Grčke. U odgovoru na proteste grčkog poslanika u Beogradu Spirosa Kapetanidisa, pomoćnik ministra Ivo Vejvoda je govorio „o masovnom iseljavanju upravo Jegejske makedonske nacionalne manjine“. Jugoslovenske vlasti su tumačile taj fenomen „kao postepenu likvidaciju te manjine kao kompaktne nacionalne grupe sa ciljem da se ona potpuno raseli“. „U takvoj situaciji mi smo prisiljeni da posmatramo i pitanje iseljavanja u Grčku Jegejskih Makedonaca koji se nalaze sada u Jugoslaviji. Mi pod takvim uslovima ne možemo dozvoliti da se ti ljudi vrate u Grčku jer bi u tom slučaju došli u opasnost da

${ }^{43}$ AJ, 836, I-3-b/281, Zabeleška o razgovoru pomoćnika ministra Vejvode sa grčkim poslanikom Capetanides-om, 7 maja 1951.

${ }^{44}$ DAMIPS, PA, Grčka, god. 1951, fasc. 30, dos. 17, sign. 46799/21. maj 1951.

${ }^{45}$ DAMIPS, PA, Grčka, god. 1951, fasc. 30, dos. 21, sign. 41828/23. januar 1951, DAMIPS, PA, દ́ o razgovoru pomoćnika ministra Vejvode sa grčkim poslanikom Capetanides-om, 7. maja 1951, ДАРМ, Главен Одбор на Здружението на Бегалците од Егејска Македонија, Извештај за положението на бежанците и мерките кој треба да се превземат.

${ }^{46}$ AJ, 836, I-3-b/281, Zabeleška o razgovoru pomoćnika ministra Vejvode sa grčkim poslanikom Capetanides-om, 7. maja 1951.

${ }^{47}$ DAMIPS, PA, Grčka, god. 1951, fasc. 30, dos. 17, sign. 46799/21. maj 1951, u: Katsanos, Makedonsko pitanje i Jugoslavija, 53. 
budu i oni iseljeni“, rekao je Vejvoda i dodao da „dok ne prestane ovo iseljavanje ne može biti govora o povratku Jegejskih Makedonaca iz Jugoslavije u Grčku“. Iako se radilo o grčkim podanicima, odgovor Jugoslavije nije naišao na oštru reakciju Atine. Kapetanidis je ponovio grčku tezu o nepostojanju „makedonske manjine" u Grčkoj i odbio svaku tvrdnju o umešanosti grčkih vlasti u proceduru iseljavanja koja se, po njemu, vršila na dobrovoljnoj osnovi u čitavoj Grčkoj zbog ekonomskih razloga. ${ }^{48}$

Jugoslovenska odluka da se obustavi masovno vraćanje izbeglica u Grčku odgovarala je grčkim stavovima. Od sredine 1951. grčke vlasti su napustile politiku oštrih tonova o repatrijaciji izbeglica, uključujući i deceizbeglica. Dugogodišnji boravak izbeglica u Jugoslaviji, po njihovom mišljenju, doprineo je njihovoj „dehelenizaciji“, odnosno „makedonizaciji“. Kako je nekoliko godina kasnije zabeležio jugoslovenski generalni konzul u Solunu Bogoljub Popović: „Grci polaze od u osnovi tačnog zaključka da je baš njihov boravak u NRM uticao na njihovu izgradnju i razvitak nacionalne svesti i da kao takvi predstavljaju takav elemenat, koji bi u slučaju povratka ozbiljno uticao na pozitivan nacionalni razvitak makedonske manjine i time ozbiljno ugrozio denacionalizatorsku politiku grčke vlade“. ${ }^{49}$ Živeći u Jugoslaviji izbeglice su, po mišljenju grčkih vlasti, bile „zaražene komunizmom“. U uslovima antikomunističke doktrine koja je vladala u Grčkoj na početku Hladnog rata to je gledište bio dodatni argumenat u sprečavanju masovnog povratka izbeglica. Atina je u takvim okolnostima nastavila politiku selektivne repatrijacije, a Jugoslavija, odnosno NRM, sredinom 1951. odlučila je da preduzme mere kojima bi se omogućio stalan boravak izbeglica u zemlji.

U narednim godinama obe države su nastavile svoju politiku. Iako je grčki konzulat u Skoplju registrovao oko 3.500 izbeglica za povratak u Grčku, grčke vlasti su odugovlačile sa izdavanjem pasoša licima koja su se prijavila za repatrijaciju. Istovremeno, jugoslovenske vlasti nisu imale jedinstven stav o repatrijaciji. Vlada NRM stajala je na stanovištu „da se ovi ljudi ne vraćaju u Grčku jer bi se i od tamo verovatno iselili, a time bi se objektivno pomogla denacionalizacija Jegejske Makedonije“. Slavomakedonski političari su, osim toga, smatrali „da to i politički ne bi bilo pravilno". ${ }^{50}$ Nasuprot tom shvatanju, federalne vlasti su povremeno uključivale $u$ dnevni red jugoslovensko-grčkih odnosa i pitanje repatrijacije izbeglica. Ti

${ }^{48}$ AJ, 836, I-3-b/281, Zabeleška o razgovoru pomoćnika ministra Vejvode sa grčkim poslanikom Capetanides-om, 7. maja 1951. Inače, pojava iseljavanja nije bila nepoznata u makedonskim krajevima, Basil Gounaris, „Emigration from Macedonia in the Early Twentieth Century", Journal of Modern Greek Studies, 7/1(1989), 133-151.

${ }^{49}$ DAMIPS, PA, Grčka, god. 1955, fasc. 21, dos. 4, sign. 42211/14. februar 1955.

${ }^{50}$ DAMIPS, PA, Grčka, god. 1953, fasc. 34, dos. 34, sign. 418443. 
pokušaji su bile manje-više formalnog karaktera, a ne u kontekstu traganja za rešenjem tog pitanja. Preduslovi koje je postavljala Jugoslavija bili su neprihvatljivi za grčke desničarske vlade. Krajem marta 1954, jugoslovenski MIP je dostavio grčkoj vladi Aide memorie u kojem je saopštio želju izbeglica da se vrate $u$ domovinu. Vlada FNRJ bi sa zadovoljstvom pozdravila mere grčke vlade koje bi omogućile rešenje tog pitanja. U tom smislu predložila je „da grčka vlada putem amnestije stvori uslove za povratak grčkih izbeglica iz Jugoslavije“" ${ }^{51}$ Grčka vlada nije dala nikakav konkretan odgovor na ovo pitanje. $^{52}$

\section{Pitanje državljanstva}

Dok je trajao oružani sukob u Grčkoj nije se postavljalo pitanje državljanstva izbeglica. Oni su imali status azilanata i njihov boravak se smatrao privremenim. Do kraja 1949. samo 7, a tokom 1950. još 63 izbeglice su postali jugoslovenski građani. ${ }^{53}$ Verovatno se radilo o izbeglicama koje su se uključile u državnu administraciju NRM ili su bili oficiri jugoslovenske armije. Kada su jugoslovenske vlasti sredinom 1951. odlučile da se obustavi repatrijacija izbeglica, pitanje državljanstva je postalo aktuelno. Davanjem državljanstva Jugoslavija bi obustavila odlazak izbeglica u Grčku ili u druge zemlje pošto bi i za njih kao jugoslovenske građane važili isti propisi o izlasku iz zemlje. Istovremeno, tim potezom jugoslovenske vlasti bi rešile probleme oko stalnog boravka izbeglica u Jugoslaviji.

Jugoslovensko rukovodstvo je sredinom 1951. počelo da preduzima mere za dugotrajno rešenje izbegličkog pitanja. U Skoplju je, 29. maja 1951, osnovana posebna komisija za izbeglice u čiji sastav su ušli najviši funkcioneri NRM. ${ }^{54}$ Pre sprovođenja mera koje bi omogućile stalan boravak izbeglica u Jugoslaviji, MIP se obratio Pravnom savetu tražeći mišljenje o sledećim pitanjima: a) da li se izbeglicama mogu dodeliti poljoprivredna imanja i sredstva za rešenje stambenog pitanja; b) da li se mogu dodeliti prava i povlastice iz zakona o ratnim vojnim invalidima; c) kako se obezbediti od eventualnih zahteva tih lica za naknadu tako stečene imovine $u$ slučaju njihovog povratka u Grčku; d) kako bi se rešenje tih pitanja odrazilo na jugoslovensko-grčke odnose. Pravni savet je odgovorio da navedena prava

${ }^{51}$ DAMIPS, PA, Grčka, god.1954, fasc. 30, dos. 30, sign. 17350/27. mart 1954.

${ }^{52}$ DAMIPS, PA, Grčka, god. 1954, fasc. 30, dos. 30, sign. 47988/23. juni 1954.

53 ДАРМ, Главен Одбор на Здружението на Бегалците од Егејска Македонија, Примањето на југословенско држављанство на Егејците и некој проблеми во врска со това, 16 декември 1954.

${ }^{54}$ Мирчевска, Нова gестиинација, 85. Članovi komisije su bili najviši funkcioneri NRM: Nikola Mirčev, Kiro Miljovski, Risto Bajalski, Elisie Popovski, Lazar Mojsov, Veselina Malinska, Naum Pejov, Vangel Ajanovski i Bančo Apostolski. 
uslovljavaju posedovanje jugoslovenskog državljanstva. U pogledu uticaja na jugoslovensko-grčke odnose, Pravni savet je predložio da se zakoni dopune opštim propisima. ${ }^{55}$

Jugoslovenske vlasti su samo delimično prihvatile argumentaciju Pravnog saveta. Najverovatnije su ocenile da preduzete mere neće izazvati reperkusije na relaciji Beograd-Atina. Prihvaćeni su argumenti o posedovanju državljanstva od strane izbeglica. Posle nekoliko dana, 20. juna 1951, u Službenom listu NRM objavljena je Uredba za izgradba stambeni zgradi na licata prebegani od Egejska Makedonija. Uredba se striktno odnosila na izbeglice koje su primile jugoslovensko državljanstvo i kao njen cilj navedeno je trajno rešenje stambenog pitanja. ${ }^{56}$ Osim stalnog smeštaja izbeglica, rešena su i pitanja vezana za propise o vojnim invalidima, penzije i druga, a istovremeno se pojačala aktivnost za učlanjenje izbeglica u Komunističku partiju. ${ }^{57}$

Budući da je preduslov za korišćenje tih povlastica bio primanje jugoslovenskog državljanstva, pojačao se pritisak izbeglica da postanu jugoslovenski državljani. Dodeljivanje državljanstva grčkim izbeglicama izazvalo je oštre reakcije u zapadnim i kominformskim zemljama. Predsednik vlade NRM Lazar Koliševski se branio rešenjima o državljanstvu i tvrdio da se cela procedura vrši na dobrovoljnoj osnovi. ${ }^{58}$ Uprkos reakcijama, procedura je tekla nesmetano. Tokom 1951. godine jugoslovensko državljanstvo primilo je 4.859 izbeglica, odnosno 1.380 muškaraca, 1.385 žena i 1.994 dece. U narednim godinama broj izbeglica koji su primili državljanstvo počeo je da opada - tokom 1952. godine 1.637, 1953. godine 1.003, a 1954. svega 320 izbeglica. Do 1954. ukupno 7.889 izbeglica su postali naturalizacijom jugoslovenski građani. U isto vreme oko 30 izbeglica su otkazali status jugoslovenskog građanina, neki su pokušali ilegalno da se vrate u Grčku, a 183 lica, uglavnom starci, doselila su se iz Grčke u Jugoslaviju radi spajanja sa porodicama. ${ }^{59}$

${ }^{55}$ DAMIPS, PA, Grčka, god. 1951, fasc. 30, dos. 17, sign. 47939; „Закон о држављанству Демократске Федеративне Југославије“, Службени лисй ДФЈ, бр. 64/45, 28. август 1945.

56 „Уредба за изградба стамбени згради на лицата пребегани од Егејска Македонија“, Службен весник на НРМ, бр. 20/51, 20. 6. 1951, 143.

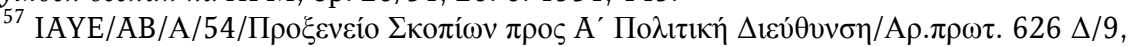
6 Iovvíov 1951 [IAYE/AB/A/54/Konzulat u Skoplju Prvoj Političkoj Direkciji/br. pr. $626 \Delta / 9$,

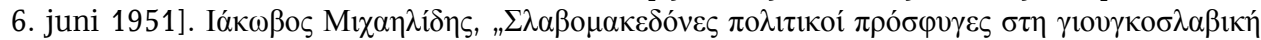

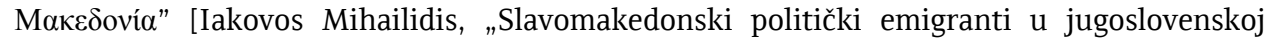
Makedoniji"], Gunaris i Mihailidis, Izbeglice na Balkanu, 57-67, Лазар Колишевски, Асиек$\bar{u}$ и на макеgонскойо йрашање, Скопје 1962, 229-230.

${ }^{58}$ Нова Макеgонија, 1-3. мај 1952.

59 ДАРМ, Главен Одбор на Здружението на Бегалците од Егејска Македонија, Примањето на југословенско држављанство на егејците и некој проблеми во врска со това, 16 декември 1954, ДАРМ, Главен Одбор на Здружението на Бегалците од Егејска 


\section{Pitanje izbegličke imovine}

U poslednjim mesecima 1944. godine i kasnije u toku Građanskog rata grčke vlasti su preuzele razne mere koje su se odnosile na imovinu grčkih državljana, a shodno tome i izbeglica koji su se kasnije iselili u Jugoslaviju.

Prva mera protiv imovine grčkih građana regulisana je zakonskim propisima o kolaboracionistima. Rešenjem specijalnih sudova prinudno je oduzimana celokupna imovina ili određeni deo imovine koja je bila u svojini lica osuđenih kao saradnici okupatora. U Florinskom okrugu, od 134 osuđenih 1945. godine kao kolaboracionisti za 48 je predviđena konfiskacija celokupne ili određenog dela imovine. U toku 1946. od ukupno 818 osuđenih 586 je podlegalo konfiskaciji imovine. Ukupno su do 1956. kao saradnici okupatora osuđena 1.462 lica, a konfiskovan je deo ili cela imovina od 1.103 osuđena. ${ }^{60}$

Druga mera koja je pogodila izbegličku imovinu sprovedena je nekoliko godina kasnije. Početkom januara 1948, u okviru napora vlade da se suzbije "komunistička buna“ u zemlji, donesen je tzv. Dekret M. Ovim dekretom je odlučeno da „sve dok traje današnja pobuna konfiskuje se cela ili deo pokretne i nepokretne imovine onih koji su: a) svojevoljni učesnici, b) osuđeni za pomoć banditskom ratu, i c) lišeni grčkog državljanstva na osnovu propisa Dekreta LZ". Po dekretu, posebna komisija je za svakog učesnika ili pomagača predložila sudu konfiskaciju imovine i sud je doneo rešenje o toj meri. ${ }^{61}$

Dekret $M$, kao i drugi pravni akti doneti od oslobođenja Grčke do stupanja na snagu novog Ustava 1952. godine, poznati su u grčkoj istoriografiji kao „paraustavni sistem“. Iako su se protivili važećem Ustavu, ti propisi su bili izjednačeni sa Ustavom i grčki sudovi su bili primorani da sude na osnovu njihovih odredaba. ${ }^{62}$ Grčka istoriografija još nije identifikovala obim primene tih akata u konfiskaciji imovine. U svakom slučaju, suđenje je prethodilo konfiskaciji, a ona je izvršena na osnovu sudskog rešenja, koje se moglo preispitati u slučaju žalbe.

Prve dve mere nisu bile uperene isključivo protiv izbeglica već protiv svih učesnika „komunističke bune“. Treća mera koja se odnosila na izbegličku imovinu sprovedena je zakonskim uredbom 2536 iz 1953. godine

Македонија, 1.996.40.60/410-414. DAMIPS, РА, год. 1956, фасц. 30, дос. 37, сигн. 411866.

${ }^{60}$ Sulidis, Specijalni sud u Florini.

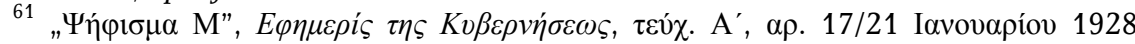
[„Dekret M“, Službeni Glasnik Kraljevine Grčke, br. 17/21 januar 1948].

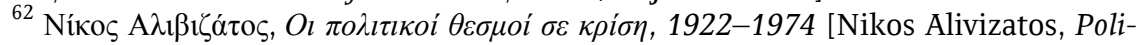
tičke instituciji u krizi, 1922-1974], Atina 1995, 492. 
„o naseljavanju i pomaganju stanovništva pograničnih oblasti“, odnosno oblasti grčke Makedonije, Trakije i Epira. Po zakonu, „nepokretno imanje sopstvenosti lica koja su ilegalno iseljena $u$ inostranstvo, bez dozvole $i$ pasoša izdatog od nadležnih vlasti, smatra se napuštenim, makar i da se isto koristi od sopstvenikovih rođaka, zastupnika ili zakupca“. Takvo napušteno imanje je prelazio u apsolutnu svojinu i korišćenje države. ${ }^{63}$ Ta mera je takođe bila uperena protiv svih grčkih izbeglica, a ne samo protiv onih koji su se iselili u Jugoslaviju.

Prema mišljenju jugoslovenskih vlasti zakon je bio „diskriminatorskog karaktera“ i ciljao je ka „izmeni etničkog sastava Egejske Makedonije i Trakije" naseljavanjem grčkog stanovništva. ${ }^{64}$ Po uobičajenoj praksi, traženo je mišljenje Pravnog saveta, koji ocenjuje da „pravno, po svom tekstu on [zakon] ne pokazuje diskriminaciju i mi, dok se ne možemo pozivati na stvarne slučajeve diskriminatorske prirode, ne možemo govoriti o diskriminaciji prema Makedoncima“. Pravni savet je smatrao da „protiv samog principa konfiskacije nekretnina izbeglih državljana ne možemo prigovoriti, jer je on prihvaćen i u našem zakonodavstvu (idemo čak i dalje jer vršimo oduzimanje nepokretnosti bez naknade i u slučaju legalnog otpusta iz državljanstva)“. U nedostatku pravnih argumenata, Pravni savet je ostavio prostor akcije na političkom polju, upozoravajući da je Grčka mogla formalno odbiti svaki jugoslovenski protest protiv zakona kao mešanje u njene unutrašnje poslove. ${ }^{65} \mathrm{U}$ narednom periodu se vodila živa diskusija između grčkih i jugoslovenskih diplomata, ali i preko novina, o zakonu na osnovu političkih argumenata, međutim svaka strana je ostala na svojim pozicijama. ${ }^{66}$

Tokom 1956. godine počeli su jugoslovensko-grčki pregovori o imovinskim potraživanjima. $\mathrm{U}$ toku priprema jugoslovenske vlasti su bile $\mathrm{u}$ dvoumici o imovinskom pitanju: smatrale su da imaju legitimno pravo postaviti pitanje pravne zaštite onih koji su primili jugoslovensko državljanstvo, iako je Jugoslavija porekla drugim državama takvo pravo. Za izbeglice koje nisu primile jugoslovensko državljanstvo, ocenjeno je da „nedostaje pravna podloga“ za postavljanje tog pitanja. Postavljanje pitanja naknade za imovinu značilo bi i da su se jugoslovenske vlasti definitivno izjasnile o stalnom boravku svih izbeglica u Jugoslaviji. ${ }^{67} \mathrm{U}$ svetlu takvih dilema jugoslovenska vlada je odlučila da ne pokreće pitanje imovine u toku pregovora sa

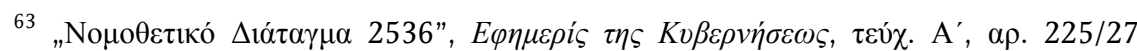

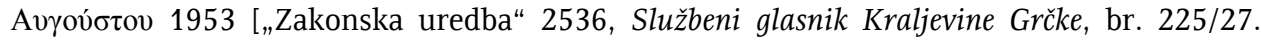
avgust 1953].

${ }^{64}$ DAMIPS, PA, Grčka, god. 1953, fasc. 31, dos. 5, sign. 417457.

${ }^{65}$ DAMIPS, PA, Grčka, god. 1953, fasc. 31, dos. 5, sign. 411799/29. avgust 1953.

${ }^{66}$ Detaljnije: Katsanos, „Nepostojeće

${ }^{67}$ DAMIPS, PA, Grčka, god. 1955, fasc. 22, dos. 2, sign. 412935/12. jul 1955. Iz priloženog dokumenta vlade NRM vidi se da se ona složila sa analizom Pravnog saveta. 
Grčkom u Beogradu aprila 1956. i u Atini juna - septembra 1956. Tome je prethodilo, počevši od sredine 1953. godine, sakupljanje podataka o imovini izbeglica. Prema oceni Ureda za zaštitu jugoslovenske imovine u inostranstvu, rezultati su bili razočaravajući. Podatke su dostavila „svega 932 lica“, a iz primljenih podataka „ne bi se mogla dobiti nikakva slika o broju, veličini i vrednosti“" prijavljene imovine. ${ }^{68}$

Ustavni sud Grčke je 1956. godine poništio kao neustavne odredbe zakona „o naseljavanju i pomaganju stanovništva pograničnih oblasti“ “ ${ }^{69}$ Tri godine kasnije, 1959, izglasan je novi zakon, koji je regulisao da ako je vlasnik imovine zatražio oduzetu imovinu u roku od tri godine od stupanja novog zakona na snagu, Ministarstvo poljoprivrede je nalagalo da se imovina vrati ili nadoknadi. ${ }^{70}$ Posle tih izmena, jugoslovenske službe su sastavile poseban izveštaj o izbegličkoj imovini. Izveštaj je trebalo dostaviti Grčkoj preko mešovite jugoslovensko-grčke komisije osnovane posle potpisivanja sporazuma o likvidiranju predratnih finansijskih potraživanja dve zemlje (1959). Vlada NRM je reagovala i povezala imovinsko pitanje sa rešavanjem svih izbegličkih pitanja. U dopisu jugoslovenskom MIP-u izrazila je mišljenje da „obzirom da $u$ današnjoj situaciji ne postoje nikakvi uslovi da se pitanje izbeglica, kao jedan kompleksan problem, rešava i reši na zadovoljavajući način, smatramo korisnim da se razmena izveštaja odloži, a ceo predmet drži otvorenim". ${ }^{71}$

Federalne vlasti su prihvatile stanovište vlade NRM i nisu dostavile Grčkoj izveštaj o izbegličkoj imovini. Pregovori u okviru Mešovite komisije o nerešenim imovinskim pitanjima između Grčke i Jugoslavije trajali su još dve godine. Pre završetka pregovora, jugoslovenski MIP je ponovo zatražio mišljenje vlade NRM o izbegličkoj imovini. Vlada NRM je odgovorila da se u pregovore sa Grčkom „ne uključi imovina egejskih Makedonaca, kao i da se prilikom izrade teksta odgovarajućeg sporazuma ne unese takva formulacija kojom bi se moglo tumačiti da je obeštećena imovina egejskih Makedonaca". ${ }^{72} \mathrm{U}$ tim okolnostima jugoslovenska strana nije postavila pitanje

${ }^{68}$ DAMIPS, PA, Grčka, god. 1957, fasc. 32, dos. 13, sign. 413506/19. jun 1957. Sudeći po podacima slavomakedonske istoriografije dobija se slika da su izbeglice bili velikoposednici u Grčkoj, Basil Gounaris, "'Communist landlords' and political refugees from Greek Macedonia“, u: www.macedonian-heritage. gr (17. decembar 2013).

${ }^{69}$ Odluka Ustavnog suda Grčke, br. 1636 iz 1956, Konstantinos Katsanos i Nada Pantelić, Makedonsko pitanje u jugoslovensko-grčkim odnosima: poverljivi dokumenti 19491967, Beograd-Solun 2012, 16-17 i 33-34 (u daljem tekstu: Katsanos i Pantelić, Makedonsko pitanje).

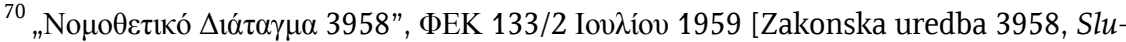
žbeni glasnik Kraljevine Grčke, br. 133/2. juli 1959; Katsanos i Pantelić, Makedonsko pitanje, 33.

${ }^{71}$ DAMIPS, PA, Grčka, god. 1962, fasc. 34, dos. 40, sign. 443538.

72 DAMIPS, PA, Grčka, god. 1965, fasc. 43, dos. 6, sign. 436794/18. septembar 1964. 
izbegličke imovine $\mathrm{u}$ jugoslovensko-grčkim pregovorima vođenim u Atini oktobra 1964. Sporazum o razmeni dvovlasničke imovine između SFRJ i Grčke potpisan je 5. novembra 1964. u Atini. ${ }^{73}$

\section{Dolazak novih izbeglica}

Posle Staljinove smrti i normalizacije odnosa Jugoslavije sa istočnoevropskim zemljama postalo je aktuelno pitanje doseljavanja izbeglica koji su bili nastanjeni u tim zemljama. Osim Jugoslavije, za to pitanje bile su „zainteresovane“ Grčka i Bugarska, ali i KPG. Spajanje porodica, poznatija sredina, bliskost sa Grčkom, ideološka ili etnička srodnost - bili su neki od razloga za novu privremenu ili konačnu destinaciju. No, mora se naglasiti da su se nove izbeglice iseljavale kao „Makedonci“, „Grci“ ili „Bugari“. Prema tome, izbor "domovine“ je podrazumevao posedovanje "domovinskog" državljanstva i „patriotsko vaspitanje“, a shodno tome i dobrovoljan ili nehotičan izbor nacionalnog identiteta. ${ }^{74}$

U januaru 1955. predsednik vlade NRM Ljupčo Arsov je izvestio delegate u Narodnom sobranju o dolasku novih izbeglica iz raznih istočnih zemalja, budući da su one dozvoljavale selidbu izbeglica u Jugoslaviju. ${ }^{75}$ Jugoslovenski MIP je 10. marta 1955. razmatrao pitanje preseljenja izbeglica i konstatovao da principijelno Jugoslavija ne može odbiti useljenje. No, učesnici su odlučili da se birokratska procedura odugovlači zbog ekonomskih razloga, ali i razloga bezbednosti. Birokratske prepreke su stavljene zbog nepoverenja prema eventualnim "Staljinovim agentima“. ${ }^{76}$ Vlada NRM se složila sa zaključcima tog sastanka, ali je posle nekoliko meseci promenila mišljenje. Krajem godine na sastanku Edvarda Kardelja, Aleksandra Rankovića, Lazara Koliševskog i Ljupča Arsova odlučeno je da pitanje spajanja razdeljenih porodica treba rešavati „svakako postupno, imajući $\mathrm{u}$ vidu u prvom redu ekonomske mogućnosti ${ }^{47}{ }^{77}$ Mada se radilo o spajanju porodica, jugoslovenske vlasti su očekivale dolazak novih 20.000-30.000 izbeglica. $^{78}$

${ }^{73}$ Katsanos, „Nepostojeće“ pitanje, 224-229.

${ }^{74} \mathrm{O}$ izbeglicama koji su se iselili u Bugarsku, Маринов, Макеgонскойо йрашање, 181-194.

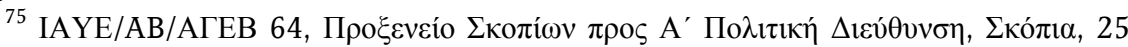

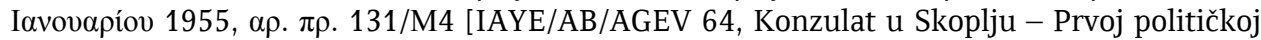
direkciji, br. pr. 131/M4, 25. januar 1955]. Upor. Нова Макеgонија, 20. januar 1955.

${ }^{76}$ DAMIPS, PA, Grčka, god. 1955, fasc. 22, dos. 30, sign. 44949.

${ }^{77}$ DAMIPS, PA, Grčka, god. 1956, fasc. 30, dos. 37, sign. 411866.

${ }^{78}$ DAMIPS, PA, Grčka, god. 1956, fasc. 30, dos. 21, sign. 423317 u: Katsanos, Makedonsko pitanje i Jugoslavija, 123-125. 
Realizacija programa je počela sredinom 1956. godine. Međutim, greškom jugoslovenske ambasade $u$ Varšavi izdata je tranzitna viza 51 grčkom emigrantu koji nisu imali grčku vizu. Kada su izbeglice stigle na grani$\mathrm{cu}$, grčke vlasti su odbile da ih prime. Grčka štampa je $u$ isto vreme iznosila tvrdnje o tobožnjim planovima za „invaziju Slavomakedonaca“, ${ }^{79}$ a grčki ambasador u Beogradu Philon Philon je preneo ministru inostranih poslova Koči Popoviću grčku uznemirenost. ${ }^{80}$ Posle grčkih reakcija, jugoslovenske vlasti su odlučile da se naseljavanje vrši umanjenim tempom i da se predstavi kao akt humanosti. ${ }^{81} \mathrm{Na}$ osnovu te odluke do 1960. godine iselilo se u NRM još 4.560 izbeglica ili oko 1.560 porodica, ${ }^{82}$ a do 1966 . broj izbeglica $u$ Jugoslaviji je iznosio 34.000 . $^{83}$

Jugoslovenska argumentacija o humanitarnoj dimenziji iseljavanja novih izbeglica u Jugoslaviju bila je neprihvatljiva za Atinu. Povremene izjave jugoslovenskih rukovodilaca o "lojalnosti“ izbeglica nisu umirile grčku vladu. Potpredsednik Kardelj je u razgovoru sa grčkim premijerom Konstantinosom Karamanlisom oktobra 1957. u Atini izjavio da „ne treba preuveličavati i nervozno primati te stvari“, jer „to je stvar humanitarnog odnosa“ ${ }^{84}$ Potpredsednik Ranković je tokom razgovora sa Karamanlisom maja 1961. u Atini izjavio da nijedna izbeglička grupa ne bi mogla da se organizuje i deluje protiv jugoslovenske politike. ${ }^{85}$ Umirujuće izjave jugoslovenskog rukovodstva o selidbi novih izbeglica primane su sa rezervom u Atini. Grčke vlasti su bile ubeđene da se u NRM formira "jedna udarna grupa“, koja bi bila spremna da se aktivira „u slučaju jednog novog Ilindena“. ${ }^{86}$ Slično je bilo mišljenje grčkog ministra za odbranu Georgiosa Melasa koji je $u$ avgustu 1965. tvrdio da u slučaju nereda Jugoslavija neće napasti Grčku, ali

${ }^{79}$ AJ, 837, I-5-b, P. DSIP Ambasadi FNRJ u Moskvi, br. 48735, Katsanos, „Nepostojeće" pitanje, 101-104.

${ }^{80}$ AJ, 837, I-5-b, Zabeleška o razgovoru državnog sekretara Koče Popovića s grčkim ambasadorom Philonom, 5. jul 1956.

${ }^{81}$ DAMIPS, PA, Grčka, god. 1956, fasc. 30, dos. 37, sign. 411866. Upor. DAMIPS, PA, Grčka, god. 1957, fasc. 32, dos. 13, sign. 421965/30. april 1957.

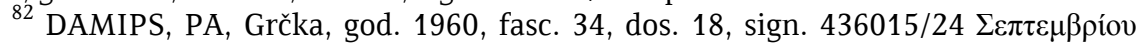
1960.

${ }^{83}$ DAMIPS, PA, Grčka, god. 1966, fasc. 48, dos. 11, sign. 435322/8. avgust 1966. Prema vladi NRM, do 1965. broj izbeglica u republici je iznosio 31.000 lica, Мирчевска, Нова gесииннаиија, 117.

${ }^{84}$ DAMIPS, PA, Grčka, god. 1957, fasc. 32, dos. 4, sign. 28863; AJ, CK SKJ, III/79, Zapisnik sa sednica Izvršnog komiteta CK SKJ, 25. oktobra 1957.

${ }^{85}$ AJ, 837, I-5-b, Grčka, Jugoslovensko-grčki razgovori za vreme posete potpredsednika Rankovića Grčkoj od 4. do 6. maja 1961.

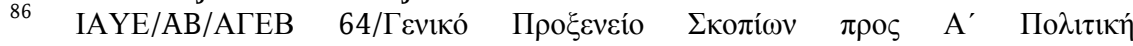

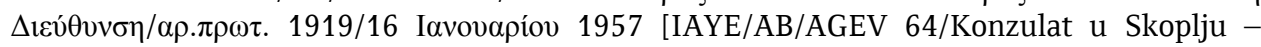
Prvoj političkoj direkciji/br. pr. 1919/16. januar 1957]. 
će se zadovoljiti invazijom izbeglica na grčku teritoriju. ${ }^{87}$ Strahovi grčkog ministra, iako preterani, bili su odraz antikomunističkog i antislovenskog raspoloženje koje je vladalo u Grčkoj tokom 50-ih i 60-ih godina.

\section{Izbeglice i nacionalni identitet}

Poznato je da u procesu stvaranja nacije značajnu ulogu imaju mitovi. U slučaju slavomakedonske nacije najznačajniji je mit o „Makedoniji u etničkim i geografskim granicama". Prema tom shvatanju, Bukureštanski ugovor iz 1913. godine uništio je i „etničko" i "geografsko“ jedinstvo „Makedonije“, dok je stvaranjem NRM oslobođen samo deo Makedonije. Posebnu ulogu su igrali i mitovi o viktimizaciji, o heroizmu, o vekovnoj borbi „Makedonaca“ za državnost. ${ }^{88}$

Mada malobrojna, izbeglička grupa u NRM, tačnije njihove vođe aktivno su učestvovali u procesu izgradnje slavomakedonske nacije. Najpre su popularisali mit o "Makedoniji“ kao domovini izbeglica, kako i mit o „Egejskoj Makedoniji“ kao „neoslobođenom“ delu „makedonske“ domovine. ${ }^{89}$ Njihov časopis Glas na Egejcite je tvrdio da „na Balkanu ne postoje tri posebne zemlje sa imenom Makedonija i tri različita makedonska naroda, već samo jedna Makedonija, koja predstavlja geografsko, etničko, ekonomsko i istorijsko jedinstvo i jedan makedonski narod, rasparčan silom balkanske buržoazije“. ${ }^{90}$ Shodno tome, Naum Pejov je isticao da „mi Makedonci iz Egejske i Pirinske Makedonije, s pravom vidimo u FNRJ našu maticu, našu širu domovinu“.$^{91} \mathrm{U}$ istom duhu redakcija Glasa je u uvodniku o „Danu Republike“ zaključila da „29. novembar, koji je povezan sa stvaranjem NRM, je i naš praznik, nas Makedonaca iz Egejske Makedonije, jer u jednom delu naše domovine postoji i razvija se makedonska nacija, koja je garancija za naše ujedinjenje“. ${ }^{92}$

U kontekstu mita o viktimizaciji, „Egejski Makedonci“ su predstavljani kao žrtve asimilacije i denacionalizacije, čak i kao žrtve genocida, a

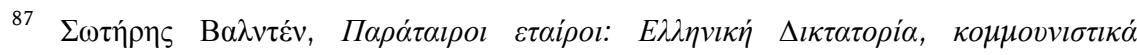

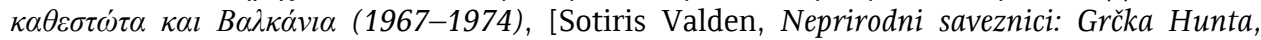
komunistički režimi i Balkan (1967-1974], Atina 2009, 356-357.

${ }^{88}$ Ulf Brunnbauer, „Drevna nacionalnost i vjekovna borba za državnost: Historiografski mitovi u Republici Makedoniji (BJRM)“, u: Historijski mitovi na Balkanu, ured. Husnija Kamberović, Sarajevo 2003, 291-328.

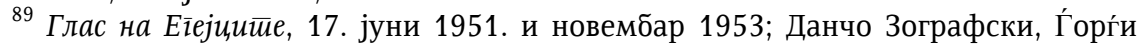
Абаџиев, Атанас Митрев, Михајло Керамитчиев, Еіејска Макеgонија во нашайа национална истиорија, Скопје 1951.

\footnotetext{
${ }^{90}$ Глас на Еїејиитее, 8. децембар 1951.

${ }^{91}$ Глас на Еїеји,йе, новембар 1953.

${ }^{92}$ Исто.
} 
Grčka kao „okupator“ i „agresor“ koji je vršio „istrebljivačku politiku“ ili politiku "svirepog terora nad Makedoncima u Egejskoj Makedoniji“. Tvrdilo se da je „grčka reakcija, predvođena kolaboracionistima, uz pomoć regularnih grupa, pljačkala, ubijala, maltretirala i gonila [Egejske Makedonce] da beže u Jugoslaviju i Bugarsku“. ${ }^{93} \mathrm{U}$ tom kontekstu je oblikovana i predstava o „exodus-u Makedonaca iz Egejske Makedonije“, uključujući i mit o „1948. godini“, o „pravnoj diskriminaciji Egejskih Makedonaca“, čak i o „teroru u egejskom delu Makedonije“. ${ }^{94}$

Uprkos demografskih promena, računalo se da je u grčkoj Makedoniji ostalo da živi kompaktno "makedonsko" stanovništvo koje se borilo za svoje oslobođenje i ujedinjenje. ${ }^{95} \mathrm{U}$ tom smislu se naglašavao mit o heroizmu i o vekovnoj borbi „Egejskih Makedonaca“ za državnost. Dva elementa su bila specifična za izbeglice: za razliku od ličnosti starijih vremena, junaci ili žrtve iz njihovih redova nisu se mogli „prisvojiti“ od Bugara, Grka ili Srba, odnosno oni su bili „dokazani Makedonci“. Njihova borba se razvila u sklopu komunističkog pokreta, još više u saradnji sa Titovim partizanima, a to je značilo da su oni bili „dokazani komunisti“. Ove prednosti su olakšavale prikaz o grčkom Građanskom ratu ne samo kao oružanom sukobu između komunista i antikomunista, već i kao ratu između grčkih nacionalista i „potiskivane manjine“. Shodno tome, Građanski rat se predstavljao kao „zlatno doba" herojske borbe „Egejskih Makedonaca“. ${ }^{96}$

Izbeglice su razvile i mit o kontinuitetu „teške i krvave borbe“ za oslobođenje „Egejske Makedonije“. U prvom broju Glasa redakcija ističe glavni zadatak časopisa: „da pokaže put po kome treba ići, a to je put Goce Delčeva i Jane Sandanskog, put Laza Trpovskog i Irene Ginove-Mirke, put za koji su dali svoj život najbolji sinovi i kćeri makedonskog naroda Egejske Makedonije“. ${ }^{97}$ Borba „Egejskih Makedonaca“ je predstavljena u svetlu

${ }^{93}$ Глас на Еїеји,ийе, март 1954.

94 Ристо Кирјазовски, „Документи за егзодусот на децата од егејскот дел на

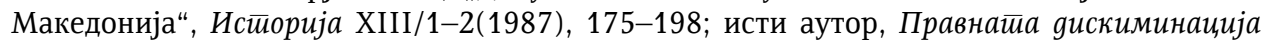

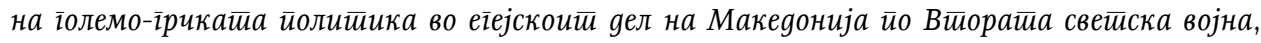

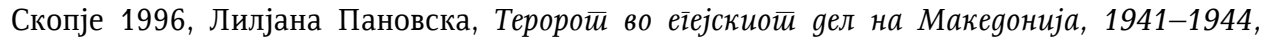

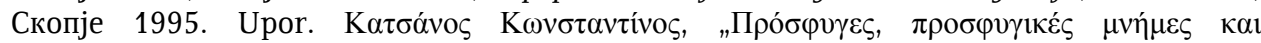
$\alpha \lambda v \tau \rho \omega \tau \iota \sigma \mu o ́ \varsigma ~ \sigma \tau \eta v ~ П Г \Delta \mathrm{M}$ [Konstantinos Katsanos, „Izbeglice, izbeglička memorija i iredentizam u BJRM]“, Gunaris i Mihailidis, Izbeglice na Balkanu, 164-212; Loring M. Danforth i Riki Van Boeschoten, Children of the Greek Civil War: Refugees and the Politics of Memory, Chicago-London 2012.

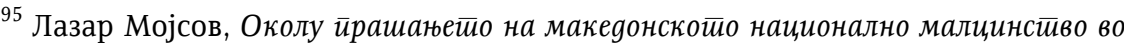
Грицја, Скопје 1954.

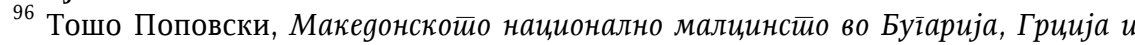
Албанија, Скопје 1981, 191-236.

${ }_{97}$ Глас на Еїеји,йе, 1. септембар 1950. Iako su Lazo Trpovski i Mirka Ginova umrli kao članovi KPG, njihove voštane figure su smeštene u Muzej koji je, između ostalog, posvećen žrtvama komunizma u Skoplju. 
ilindenskih tradicija, a nešto kasnije, u sklopu narodnooslobodilačkih pokreta koji su se razvili tokom 19. veka. Andonovski je otkrio „makedonski“ karakter Privremene vlade Makedonije iz 1880. godine, koja je inače tražila ujedinjenje regiona sa Grčkom, a Todor Simovski je pisao o „makedonskom" karakteru ustanka u Nausi (1822), koji je u slavomakedonskoj istoriografiji postao poznat kao „Njeguško vostanie““.98

Tokom šezdesetih i sedamdesetih godina „egejska inteligencija“ se ojačala uključivanjem istoričara koji su studirali u Skoplju (Krste Bitovski, Risto Kirjazovski) ili onih koji su se kasnije doselili u NRM (Risto Poplazarov, Stojan Kiselinovski, Spiridon Blagoev i drugi). Delatnošću „egejskih“ istoričara, istorija „Egejske Makedonije“ je postala deo nacionalne „makedonske" istorije. Kao takva se pojavila u Istoriji makedonskog naroda koja je objavljena 1969. godine. ${ }^{99} \mathrm{U}$ isto vreme, preko jugoslovenskih časopisa shvatanja slavomakedonske istoriografije su se proširila po celoj Jugoslaviji i postala deo zvanične jugoslovenske istoriografije. ${ }^{100}$

Peta decenija 20. veka je bila kobna za razvoj makedonskog pitanja. Do tada je makedonsko pitanje bilo pitanje uključivanja dela ili cele makedonske geografske teritorije $u$ nacionalne države Bugarske, Grčke i Srbije. Priznavanjem "Makedonaca" kao posebne nacije i stvaranjem NRM kao nacionalne "makedonske“ države Titova Jugoslavija se pojavila kao najjači pretendent za rešavanje makedonskog pitanja. NRM je trebalo da postane pijemont oko kojeg bi se ujedinile makedonske teritorije u sklopu Jugoslavije. Kraj decenije, međutim, izneverio je ta očekivanja.

Izbeglice su se našle u vrtlogu ovih događaja. U slučaju pobede njihovih istomišljenika u Grčkoj oni bi se vratili kao heroji. No, izašli su iz rata kao poraženi. Izbegličko rukovodstvo nije se pomirilo sa porazom i pokušalo je da nastavi borbu drugim sredstvima. Ubrzo je shvatilo da su izneverena i njihova politička očekivanja. Titova Jugoslavija je uspostavila srdačne odnose sa bivšim neprijateljima. Bilo je samo pitanje vremena da se reše, onako kako su rešena, pitanja njihovog državljanstva i nacionalnog identiteta. Posle toga, istorija je bila jedini put koji bi mogao ublažiti njihovo razočarenje takvim razvojem događaja i jedino polje koje im je moglo dati opravdanje za sve što im je politikom i diplomatijom bilo uskraćeno. Izbeglice su dobile status zvaničnog tumača ne samo svoje prošlosti već i istorije „Egejske Makedonije“ uopšte. Njihovo služenje naciji na tom polju bilo je veoma uspešno. Bila je ta zakašnjela pobeda za njihove patnje u izgnanstvu.

\footnotetext{
${ }^{98}$ Нова Макеgонија, 2. август 1953.

${ }^{99}$ Истиорија на макеgонскиоти нароg, књ. 3, Скопје 1969, 245-275, 313-316, 323325, 376-382, 418-422, 435-437.

${ }^{100}$ The Historiography of Yugoslavia 1965-1975, Belgrade 1974, p. 298-323.
} 
Konstantinos Katsanos

IN THE NEW HOMELAND

Refugees from the Greece in the Yugoslav Republic of Macedonia

\section{Summary}

The article is based on archival sources and literature which deals with the issue of refugees who fled from Greece to the Yugoslav Republic of Macedonia during the late 1940s. It reconstruct the creation and structure of refugee groups, and analyzes the question of repatriation, citizenship and property of refugees in the context of the Yugoslav - Greek relations. It provides a brief review of the contribution of the refugees in the process of creation of the Slavo-Macedonia nation. 